\title{
Using Blended Learning Approach (BLA) in Inclusive Education Course: A Study Investigating Teacher Students' Perception
}

\author{
https://doi.org/10.3991/ijet.v15i02.9285 \\ Rasmitadila $\left.{ }^{(}\right)$, Widyasari, Megan Asri Humaira \\ Universitas Djuanda, Jawa Barat, Indonesia \\ rasmitadila@unida.ac.id \\ Anna Riana Suryanti Tambunan \\ Universitas Negeri Medan, Sumatera Utara, Indonesia \\ Reza Rachmadtullah \\ Universitas PGRI Adibuana, Jawa Timur, Indonesia \\ Achmad Samsudin \\ Universitas Pendidikan Indonesia, Jawa Barat, Indonesia
}

\begin{abstract}
The purpose of this study is to explore students' perceptions about the application of blended learning (BLA) approach in inclusive education courses. Thirty (30) students participated in this study. Data collection is done by open interviews to find out student perceptions about the application of integrated learning. The results of the interviews were analyzed using content analysis techniques. Based on data analysis, there are four categories of student attention, namely: the display of learning management systems (LMS); accessibility; benefits and sustainability. Students' perceptions of the appearance of LMS on the web are following the learning objectives but must be modified to make it easier for students to understand. Internet accessibility in the campus environment to the web is still unstable and slow. Benefits of BLA for students can add to the learning experience, knowledge, variations in learning models, learning more flexible and independent. Students hope that BLA can be continued because it can increase students' interest in learning, learning is more modern, flexible and independent.
\end{abstract}

Keywords - Blended learning, student teacher, inclusive education course

\section{Introduction}

The development of the internet and communications technology has grown very swiftly and has a massive impact in various aspects, including in education. The development of communication technology causes changes in human behavior [1][2][3] in conducting activities to fit the needs, velocity, and easiness in achievement. No 
exception in the field of education, the development of information and communication technology has brought the direction and process to achieve the goal of education becomes easier. Classroom-based learning and lectures, or face-to-face meetings between learners and educators are not the only way of learning although all this time studying face-to-face are still more done in class included in college [4][5][6].

As information and computer technology (ICT) evolves, various learning approaches that have developed based on the internet, web or e-learning provide an alternative for the implementation of learning to become more varied, although inevitably there are still problems to solve. The possibility of the highest level of education in the application of ICT is the college. The college community consisting of students, faculty and staff are people who understand rapidly the development of ICT which is then widely applied in learning. The increasing trend in ICT utilization is the most commonly used blended learning approach (BLA). According to [7] that BLA has become one of the most widely used methods in universities and as many as $80 \%$ of universities are beginning to use BLA to gain meaningful learning as well as experience in learning significantly [8][9] the use of BLA has provided many benefits, with $94 \%$ of lecturers saying that BLA is one of the more active learning approaches compared to just face-to-face learning [10]. BLA also provides opportunities for teachers and students to collaborate and interact with each other in education so that learning experiences can be obtained properly. Use of BLA is one approach that combines face-to-face learning with online with the principle of face-to-face oral communication with integrated online communication optimally so that students get an in-depth learning experience, unique according to the intended purpose [11].

The BLA is a learning concept that uses a combination of e-learning methods with traditional methods that can provide solutions, provide benefits and is very useful in both classroom and organizational learning [12]. One way of achieving learning objectives especially in higher education is to modify or restructure the learning system. The idea that can be used is a combination of face-to-face and online or blended learning systems so that the students get an exciting learning experience, deep and meaningful learning. Some critical keys in the BLA are that BLA integrates face-toface education with online, designing systems to optimize student engagement, achieving educational goals by optimizing face-to-face and online learning. Blended learning reveals a learning evolution that focuses on the use of technology development that is integrated with traditional education such as face-to-face which is the answer to learning challenges in the current era. Blended learning is a combination of multimedia technology, video streaming CD ROM, virtual class, voicemail, email and conference calls, online text animation and video streaming [13].

The use of BLA in universities is not without obstacles, especially the utilization and internet usage that has not been maximally done [14][15][16]. Various barriers that often occur are the provision of internet facilities and infrastructure that still cannot accommodate online capacity and internet speeds that again cannot meet the availability of internet for students and lecturers [17][18][19][20]. This picture has caused the implementation of BLA which has been pioneered previously encountered difficulties which resulted in the cessation of BLA usage in the following semesters. Other challenges are related to the skills of lecturers using the web such as the display 
of learning management system (LMS) or other web usages. Behind all obstacles or difficulties faced in the application of BLA, but the purpose of using BLA has provided significant benefits for educational purposes [21][22] both for students and for teaching staff. For the BLA system to continue to carry out smoothly and sustainably, it is expected that evaluations and suggestions from direct users, namely students and lecturers must carry it out. It is intended that the academics will feel the implementation of BLA in universities.

The purpose of this study was to explore teacher students' (TS) perceptions of the implementation of blended learning in the inclusive education course. For this reason, the research question in this study is how the TS's perceptions of the implementation of blended learning in the inclusive education course?

\section{$2 \quad$ Methodology}

The inclusive education course is one of the compulsory subjects that must be taken by the 5th-semester students in the elementary school teacher education of study program in the university. The number of TS taking this course is 90 students. In this study, BLA is used in a balanced way between the use of online with learning media consisting of LMS, video, social media and face-to-face learning in the classroom. The number of meetings conducted during a semester in the BLA which is held in the LMS as many as ten meetings. Table 1 shows the subject of inclusive education in one semester.

Table 1. Subject of inclusive education in one semester

\begin{tabular}{|c|l|l|}
\hline Meetings & \multicolumn{1}{|c|}{ Topics } & \multicolumn{1}{|c|}{ Method of BLA } \\
\hline 1 & The history of inclusive education & Face-to-face in the classroom (traditional) \\
\hline 2 & $\begin{array}{l}\text { The development of inclusive education in Indo- } \\
\text { nesia }\end{array}$ & $\begin{array}{l}\text { Chat discussion (self-study), video (Asyn- } \\
\text { cronous) }\end{array}$ \\
\hline 3 & Implementation of inclusive education & $\begin{array}{l}\text { Video (independent learning), video, anima- } \\
\text { tion (Asyncronous) }\end{array}$ \\
\hline 4 & $\begin{array}{l}\text { Characteristics of learners in an inclusive class- } \\
\text { room }\end{array}$ & Face-to-face in the classroom (traditional) \\
\hline 5 & Student identification and assessment & Face-to-face in the classroom (tradicional) \\
\hline 6 & Curriculum of inclusive education & Face-to-face in the classroom (tradicional) \\
\hline 7 & Educator in inclusive class & Teleconference (synchronous) \\
\hline 8 & Inclusive school management & Teleconference (synchronous) \\
\hline 9 & Learning in inclusive classes & $\begin{array}{l}\text { Face-to-face in the classroom (traditional) } \\
\text { nous) }\end{array}$ \\
\hline 10 & Evaluation of inclusive learning & \\
\hline
\end{tabular}




\subsection{Participant}

Participants consisted of an interview group by selecting 30 TS from 90 students who took inclusive education courses in the 5th semester of the academic year 20172018 of the private university in West Java Indonesia. Elected group members consist of 10 students with high, medium and low academic achievement using face-to-face techniques. The selection of student categories (high, medium and low) is based on student learning outcomes in the previous semester, in the form of cumulative lesson indexes, activeness in the classroom during learning takes place mainly in class discussion activities and in LMS. The value of the discussion is directly given to students in the LMS based on the assigned assessment rubric. These assessments will be ranked by the lecturer and will be selected as a sample in this study. This grouping of samples is done to obtain the right data and can provide honest information comparing the courses with the conventional model.

\subsection{Data collection}

Data collection was conducted with semi-structured face-to-face interviews, which have been designed to identify and identify TS perceptions. The questions provided consist of 10 open questions to get more in-depth data. Interview questions are validated to 2 experts who have blended learning expertise and make revisions according to the direction of the expert. The interview was conducted for three days, with ten people every day with an average duration of 3-4 hours. The primary data obtained is recorded which is then made a transcript by the researchers to be analyzed further.

\subsection{Data analysis}

Data analysis used in this research uses qualitative data analysis. Analysis of qualitative data is one approach that is very flexible for researchers, making it easier for researchers to understand the data collected and can be accounted for appropriately. Analysis of qualitative data is related to interconnected data patterns [23]. Analysis of qualitative data following the data collected can provide terminology in a qualitative text. Unlike quantitative data analysis, which uses a lot of numerical data, qualitative data analysis more often displays contextual data from an event and gives freedom to researchers [24].

Before the data is analyzed further, the first step is to make transcripts from interviews. In the interview results, the following steps were taken:

- Reviewing interviews records that determined the phrases related to the most commonly mentioned to BLA

- Finding and identifying phrases appropriate to BLA

- Make a code and the category of each identification result

- Calculate the percentage of each type (positive and negative perceptions). 
The next step is to perform the data analysis process. The researcher applied qualitative data analysis developed by [25] and modified by [26] with three analysis steps, that were:

- Thematic analysis of all participants, combining the results of coding and interviewing all TSs

- Within-participant thematic study, identified the general theme of each category

- Cross-participant analysis, identifying the general issue of the BLA category between the participants

The final stage of analyzing the use of BLA is the culture theme as a profile of TSs perceptions of the use of BL. Below is the process of analysis results:

Table 2. Thematic-qualitative data analysis

\begin{tabular}{|l|l|l|}
\hline \multicolumn{1}{|c|}{ Included term } & Semantic relationships & \multicolumn{1}{c|}{ Cover term } \\
\hline $\begin{array}{l}\text { Video, Quality Image, The command, The } \\
\text { Qolor and appearance }\end{array}$ & Is kind of & Display of LMS \\
\hline Easy access, Internet, Access Time & Is kind of & Accessibility \\
\hline $\begin{array}{l}\text { Learning experience knowledge, Learning } \\
\text { model }\end{array}$ & Is kind of & Benefit of BLA \\
\hline Learning interest modern learnning & Is kind of & Sustainability of BLA \\
\hline
\end{tabular}

\section{$3 \quad$ Result and Discussion}

As a result of the coding carried out, four categories have been grouped, namely: display of LMS on the web, accessibility, benefits of BLA and sustainability of BLA. The results of each type are explained in the following results:

\subsection{Display of LMS}

The display of LMS is a question given to participants in the form of participants' perceptions about the display on the web that must be opened. Table 2 is the result of participants' perceptions of the LMS display. The TS' positive and negative perceptions of the LMS display are illustrated in Table 3 below:

Table 3. Frequency and perception of student to display LMS on the web

\begin{tabular}{|c|c|c|c|c|c|c|}
\hline \multirow{2}{*}{ Categories } & \multicolumn{2}{|c|}{ Possitive perceptions } & Negative perceptions & \multicolumn{2}{|c|}{ Total } \\
\cline { 2 - 7 } & $\boldsymbol{F}$ & $\boldsymbol{\%}$ & $\boldsymbol{F}$ & $\boldsymbol{\%}$ & $\boldsymbol{F}$ & $\boldsymbol{\%}$ \\
\hline Display LMS on the web & 16 & 53.33 & 14 & 46.67 & 30 & 100 \\
\hline
\end{tabular}

In Table 3, the positive perceptions of students towards LMS on the Web are higher than the negative perception of students. Positive perceptions can be seen more clearly in Table 4 below: 
Table 4. TSs perceptions about the appearance of the LMS

\begin{tabular}{|c|c|c|}
\hline Category & Positive pereption & Negative perception \\
\hline \multirow{4}{*}{ Display of LMS } & The video is very clear & Video duration should not be too long \\
\hline & Image quality is representative of the topic & Image resolution is too large \\
\hline & The command on the LMS is clear, simple & The order is less detailed \\
\hline & $\begin{array}{l}\text { The colour and appearance of the letters are very } \\
\text { appropriate }\end{array}$ & $\begin{array}{l}\text { It is difficult to distinguish between } \\
\text { asynchronous and synchronous LMS }\end{array}$ \\
\hline
\end{tabular}

In Table 4, there are some positive perceptions of the TS that are the basis for the class to begin the course following the agreed course objectives. The use of LMS in which there is the use of video, pictures, including instructions or instructions to be done by students has been able to run well by students.

Although there are still negative perceptions of video duration, too high picture resolution, instructions on information relating to the implementation of the lesson, or the quiz given by the lecturer are expected to be elaborated in detail so that the students can easily understand what to do. Besides, another negative perception is those TS' difficulties in distinguishing between synchronous and synchronous models during the learning process. This condition causes students to be able to check the LMS display and differentiate between the two models. Figure 1 below is an example of an LMS display that still needs a revision for use in the same subject in the following semester.

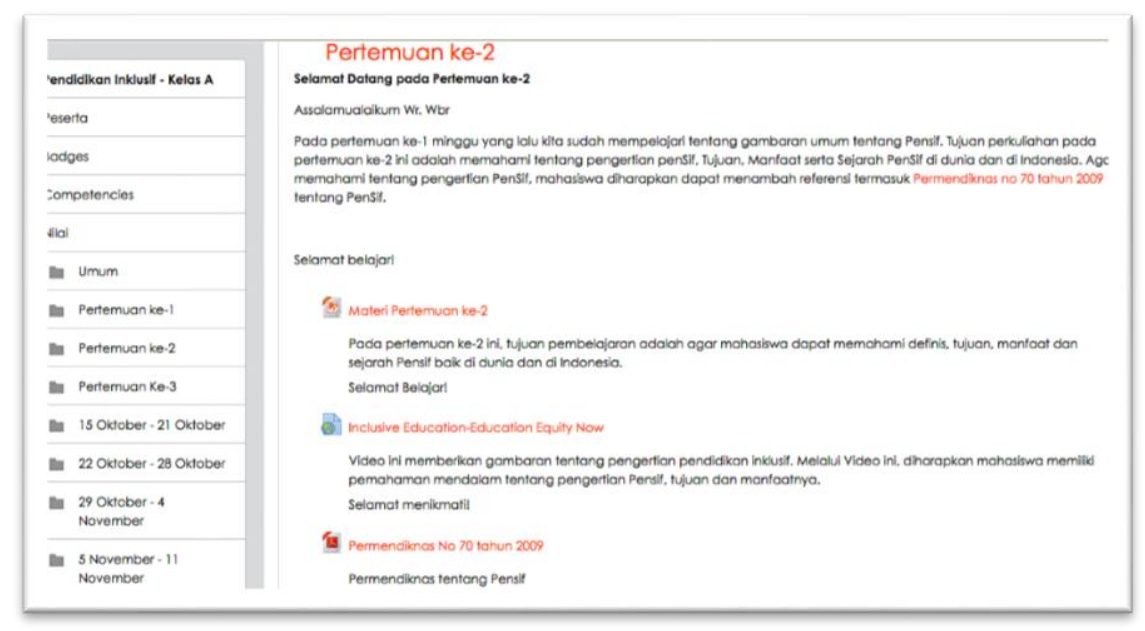

Fig. 1. Display of LMS

\subsection{Accessibility}

Accessibility is easy to access provided to students to apart easily to know the subject matter that will be delivered by lecturers. Both positive and negative attitudes of TS come for various reasons such as tables in Table 5: 
Table 5. Frequency and perception of student toward accessibility to LMS

\begin{tabular}{|l|c|c|c|c|c|c|}
\hline \multirow{2}{*}{ Categories } & \multicolumn{2}{|c|}{ Possitive perceptions } & \multicolumn{2}{c|}{ Negative perceptions } & \multicolumn{2}{c|}{ Total } \\
\cline { 2 - 7 } & $\boldsymbol{F}$ & $\boldsymbol{\%}$ & $\boldsymbol{F}$ & $\boldsymbol{\%}$ & $\boldsymbol{F}$ & $\%$ \\
\hline Accessibility & 6 & 20 & 24 & 80 & 30 & 100 \\
\hline
\end{tabular}

In Table 5, the positive perception of students towards accessibility is lower than the negative perception of students. Positive perceptions can be seen more clearly in Table 6 below:

Table 6. TS' perceptions of accessibility to the LMS

\begin{tabular}{|c|c|c|}
\hline Category & Positive pereption & Negative perception \\
\hline \multirow{4}{*}{ Accessibility } & $\begin{array}{l}\text { Easily access the internet to enter the web } \\
\text { while on campus }\end{array}$ & Internet speed is still slow \\
\hline & $\begin{array}{l}\text { Free internet use on campus to enter the } \\
\text { web. }\end{array}$ & The internet is often unstable \\
\hline & $\begin{array}{l}\text { Can access the internet at any time on } \\
\text { camous }\end{array}$ & Not many students have internet access at home \\
\hline & & $\begin{array}{l}\text { The high price of internet packages to be able to } \\
\text { access the blend learning web }\end{array}$ \\
\hline
\end{tabular}

The TS's positive perception of accessibility is less than the contrary opinion. These results indicate that there are obstacles that must be faced by the campus to be able to provide better access to the Internet. The use of the Internet that can only be used by TSs in the campus area, with unlimited quota, actually provides opportunities for students to be able to take advantage of this condition. On the other hand, the cause of the internet to become slow and unstable is a large number of users accessing the web. Meanwhile, not many TSs have internet packages that can be used at home to access the network. The high cost of internet package for student sizes is one of the obstacles that TSs and campus have to face for the TS to learn blended learning but can take place.

\subsection{Benefits of BLA}

Table 7. Frequency and perception of student toward the benefits of BLA

\begin{tabular}{|l|c|c|c|c|c|c|}
\hline \multirow{2}{*}{ Categories } & \multicolumn{2}{|c|}{ Possitive perceptions } & \multicolumn{2}{c|}{ Negative perceptions } & \multicolumn{2}{c|}{ Total } \\
\cline { 2 - 7 } & $\boldsymbol{F}$ & $\boldsymbol{\%}$ & $\boldsymbol{F}$ & $\boldsymbol{\%}$ & $\boldsymbol{F}$ & $\boldsymbol{\%}$ \\
\hline Accessibility & 19 & 65 & 11 & 35 & 30 & 100 \\
\hline
\end{tabular}

In table 7 , the positive perception of students towards accessibility is higher than the negative perception of students. Positive perceptions can be seen more clearly in Table 8 below: 
Table 8. TS's perceptions about the benefits of BLA

\begin{tabular}{|c|l|l|}
\hline Category & \multicolumn{1}{|c|}{ Positive pereption } & \multicolumn{1}{c|}{ Negative perception } \\
\hline \multirow{3}{*}{ Benefits of use BLA } & Add of the learning experience & $\begin{array}{l}\text { Requires special attention and costs } \\
\text { beyond tuition }\end{array}$ \\
\cline { 2 - 3 } & Add knowledge of ICT & $\begin{array}{l}\text { Often open another web that is not } \\
\text { necessary }\end{array}$ \\
\cline { 2 - 3 } & Familiar with variations of learning models & Still cannot master ICT \\
\cline { 2 - 3 } & Learn more flexible and independent & \\
\hline
\end{tabular}

Based on the perception of TSs in Table 8 , the benefits of BLA more perceived benefits than the negative things understood by the TSs. In addition to this new model was first applied in one lecture, causing the TS still consider it as a learning experience that needs to learn including the benefits in obtaining the value and knowledge that will be obtained.

\subsection{Sustainability of BLA}

Sustainability of BLA is one of the indicators that BLA has become one of the learning models that provide benefits for TSs, so it must be continuously applied in learning.

Table 9. Frequency and perception of student toward the sustainability of BLA

\begin{tabular}{|l|c|c|c|c|c|c|}
\hline \multirow{2}{*}{ Categories } & \multicolumn{2}{|c|}{ Possitive perceptions } & \multicolumn{2}{c|}{ Negative perceptions } & \multicolumn{2}{c|}{ Total } \\
\cline { 2 - 7 } & $\boldsymbol{F}$ & $\boldsymbol{\%}$ & $\boldsymbol{F}$ & $\boldsymbol{\%}$ & $\boldsymbol{F}$ & $\boldsymbol{\%}$ \\
\hline Accessibility & 21 & 70 & 9 & 30 & 30 & 100 \\
\hline
\end{tabular}

In table 8 , the positive perception of students towards accessibility is higher than the negative perception of students. Positive perceptions can be seen more clearly in Table 9 below:

The perception of the sustainability of BLA is shown in Table 7 below:

Table 10. TS's perception about sustainability of BLA

\begin{tabular}{|c|l|l|}
\hline Category & \multicolumn{1}{|c|}{ Positive pereption } & \multicolumn{1}{c|}{ Negative perception } \\
\hline \multirow{4}{*}{ Stability of BLA } & Interest in learning increases & Dificult to apply \\
\cline { 2 - 3 } & Familar with variations of learning models & Facilites and infrastructure are inadequate \\
\cline { 2 - 3 } & Learning to be more modern & Still cannot master ICT \\
\cline { 2 - 3 } & Learn more flexible and independent & \\
\hline
\end{tabular}

The implementation of the BLA is expected to provide benefits to utilize and adapt the development of information technology. Through BLA, student learning is not only limited to classrooms, but opportunities and learning time can also be more flexible and independent. 


\section{Discussion}

Display on the LMS that contains the profile of the course, the number of meetings in which there is content that must be learned by the student is the main view which of course must be designed by the team of lecturers so that TS can easily understand the learning model, especially the content of the lecture material to study. In addition to learning the content, the assignment of exercises, assignments (project, observation) is complete in LMS. As a consequence, TS must check LMS every day. LMS helps TS to bridge the interaction between lecturers and TS so that the learning takes place independently, using both online and offline systems. According to students, the appearance of LMS is still dull. It still has to be modified to make it more useful. The TS' opinions about LMS content are as follows:

"In my opinion, this LMS display is already good, the colors and letters are appropriate. Orders from the lecturer are also clear, only lacking details. So I am somewhat difficult to tell the difference, because this is my first experience learning to use blended learning method ". (Student 1)

Another opinion is:

"I hope the LMS display will be even better, so it doesn't confuse me" (Student 2).

The appearance of LMS is indeed significant to be able to be made more exciting and accessible to students. The aim is for students to understand the material to be learned quickly. Lecturers must be able to modify the appearance to make it more attractive, so students are interested in learning [25][26].

Accessibility is an absolute means that must be in place, and it is certain that users can be easily accessed by users of the BLA [27][28]. If access is challenging to reach by students, the learning process is trying to do, even though the BLA relies heavily on adequate internet access. This opinion is by the following views of one of the TS:

"I love learning model blended learning. But I often find it difficult to access the internet on campus, even though the campus has freed all students to access the campus internet. But still because many users so the internet is not stable and slow. This of course can hamper my learning "(Student 3).

Other students argue:

"For me, learning through the web is very good because it can make me more independent. But often I don't have a data package, so it's difficult to download material. On the campus the internet is very slow" (Student 4)

Internet access should be provided stably and efficiently so that every student is comfortable to know the content or material that must be learned in a learning meeting. Ease of access gives students the learning space so that they have motivation and interest in learning [29][30], but if access is complicated it will create obstacles in education. So that it is an obstacle in learning [31][32].

Various benefits are gained as a way that learning is now not limited to do with face-to-face conventionally that has been done between educators and learners. But now it is learning to give space and an outdoor opportunity to learn at any time, anywhere. This goal is of course not far from the framework and learning objectives of 
the material being studied [33][34][35]. This opinion is in line with one TS's view, as below:

"In my opinion, this blended learning model is one of the modern models that provide opportunities for students to be able to learn more flexible and independent. I can learn from home according to the direction of the lecturers, so I can learn more independently. Indeed some obstacles for me, such as dividing the special time in order to concentrate on the course I was living using blended learning. Together so far for me more benefits for future learning "(Student 3)

The benefits of BLA provide an opportunity for educators and learners [36] [37][38]to stay in touch with each other in learning and have the same level of learners. Implementation of learning that has been limited to the conventional or face-toface in the classroom, and modified online learning provides increasingly diverse education and offers the choice to learners to be more advanced in learning. Students have access to flexible and easy lecture materials [39][40][41]. Students are expected to keep pace with the rapid advancement of communication technology that should continue to evolve. Although the challenges or difficulties faced by students are also not small, that is still the number of students who do not understand ICT [42], interest to open the web other than web blended learning, is a challenge that should be prevented if students understand the real learning objectives.

The sustainability of the BLA for students is of course very much needed because it has provided benefits to students. Benefits that should be followed by the improvement of supporting facilities and supporting BLA is expected to minimize the shortcomings faced by lecturers and students for the sake of mutual progress. For this reason, the improvement and adoption of BLA are essential to continue. This condition is by the following student opinions:

"For me, the first time I applied blended learning, this is the latest way for students not only to learn to rely on face-to-face as they have done so far. It is time for me to be able to use technology that supports my learning. I hope that the blended learning model can continue to be used, in addition to improving the difficulties faced, especially the problem of unstable internet access "(Student 4)

The utilization and the use of BLA so far still requires changes, improvements, and additions to facilities that can support the success of learning. Impacts felt by students such as self-reliance in education can foster more significant interest in learning, So that learning is not only dependent on face-to-face lecturers only. The use of BLA for students which is one of the learning innovations in higher education provides a new way of learning [47]. Of course, the use of BLA is intended so that the learning process between lecturers and students is expected to be more comfortable, independent and learning is not limited to space and time [48]. This study illustrates, although there are still obstacles that still need to be addressed by the university as learning designers, student opinions are significant to note. Web appearance, accessibility, BLA benefits, and BLA sustainability are common obstacles often faced by BLA users, especially at the University.

The results of this study provide recommendations to students that through the mixing of online and face-to-face learning, students will not lose the spirit of education, but instead, provide an opportunity for students to learn more flexible and inde- 
pendently [43][44][45][46]. The task for teachers, learning designers and ICT sections of universities is critical and must work together so that a good system is built in using BLA for the future. Meanwhile, educational designers can improve and design learning-friendly BLAs and make it easier for students and teachers to apply them to learning.

\section{Conclusion}

The results of student perceptions of BLA can be concluded based on four categories namely the appearance of LMS on the web, accessibility, benefits of BLA and sustainability of BLA. The most prominent perception in a row shows that $69.57 \%$ of TS' negative perception about accessibility means that internet access to the web is still not stable a nd slow. The positive perception of the benefits of BLA by $66.94 \%$ shows that BLA provides good benefits for TS, especially regarding increasing learning experience, knowledge, variations in learning models and learning more flexible and independent. The positive perception of BLA sustainability of $66.18 \%$ shows that BLA must continue because it can increase TS's learning interest, learn more modestly, more flexible and independent. A positive perception of the appearance of LMS on the web by $50.53 \%$ indicates that the presence of the LMS is appropriate and straightforward, although it still has to be modified to make it easier for TSs to understand. In general, it can be concluded that the BLA can be a modern learning alternative that is adapted and utilized the development of technology and communication.

\section{$5 \quad$ References}

[1] S. Salleh and K. Laxman, "Examining the Effect of External Factors and ContextDependent Beliefs of Teachers in the Use of ICT in Teaching: Using an Elaborated Theory of Planned Behavior," J. Educ. Technol. Syst., vol. 43, no. 3, pp. 289-319, 2015. https:// doi.org/10.1177/0047239515570578

[2] P. Altass and S. Wiebe, "Re-imagining Education Policy and Practice in the Digital Era," J. Can. Assoc. Curric. Stud., vol. 15, no. 2, 2017.

[3] G. Pretto and G. Curró, "An approach for doctoral students conducting context-specific review of literature in IT, ICT, and educational technology," New Rev. Acad. Librariansh., vol. 23, no. 1, pp. 60-83, 2017. https://doi.org/10.1080/13614533.2016.1227861

[4] R. Hauser, R. Paul, and J. Bradley, "Computer self-efficacy, anxiety, and learning in online versus face to face medium," J. Inf. Technol. Educ. Res., vol. 11, pp. 141-154, 2012. https://doi.org/10.28945/1633

[5] C. G. Skeen, Comparing interactions in literature circles in both online and in class discussions. Sam Houston State University, 2014.

[6] S. Schmidt, The rush to online: Comparing students' learning outcomes in online and faceto-face accounting courses. University of South Dakota, 2012.

[7] C. J. Bonk and C. R. Graham, The handbook of blended learning: Global perspectives, local designs. John Wiley \& Sons, 2012.

[8] P. Arabasz and M. B. Baker, "Evolving campus support models for e-learning courses," Educ. Cent. Appl. Res. Bull., pp. 1-9, 2003. 
[9] Y. Zhonggen, "Blended learning over two decades," in Professional Develop-ment and Workplace Learning: Concepts, Methodologies, Tools, and Applica-tions, IGI Global, 2016, pp. 1248-1267. https://doi.org/10.4018/978-1-4666-8632-8.ch068

[10] C. Marquis, "WebCT survey discovers a blend of online learning and class-room-based teaching is the most effective form of learning today," WebCT Com, 2004.

[11] D. R. Garrison and N. D. Vaughan, "Blended Learning in Higher Education," SPH P, p. 265, 2007.

[12] D. Wilson and E. M. Smilanich, The other blended learning: a classroom-centered approach. John Wiley \& Sons, 2005.

[13] K. Thorne, Blended learning: how to integrate online \& traditional learning. London ; Sterling, VA: Kogan Page, 2003.

[14] S. Gyamfi and P. Gyaase, "Students' perception of blended learning environ-ment: A case study of the University of Education, Winneba, Kumasi-Campus, Ghana," Int. J. Educ. Dev. Using ICT, vol. 11, no. 1, 2015.

[15] C. M. Tang and L. Y. Chaw, "Digital Literacy: A Prerequisite for Effective Learning in a Blended Learning Environment?.," Electron. J. E-Learn., vol. 14, no. 1, pp. 54-65, 2016.

[16] O. Darojat, "Improving Curriculum through Blended Learning Pedagogy.," Turk. Online J. Distance Educ., vol. 17, no. 4, pp. 203-218, 2016. https://doi.org/10.17718/tojde.72654

[17] T. Szimkovics, "Blended Learning Opportunities in Ukrainian IT Public Educa-tion," Pract. Theory Syst. Educ., vol. 12, no. 2, pp. 60-70, 2018.

[18] B. Asuman, M. S. H. Khan, and C. K. Clement, "Integration of Web-Based Learning into Higher Education Institutions in Uganda: Teachers' Perspec-tives," Int. J. Web-Based Learn. Teach. Technol. IJWLTT, vol. 13, no. 3, pp. 33-50, 2018. https://doi.org/10.4018/ ijwltt.2018070103

[19] C. C. Wai and E. L. K. Seng, "Measuring the effectiveness of blended learning environment: A case study in Malaysia," Educ. Inf. Technol., vol. 20, no. 3, pp. 429-443, 2015. https://doi.org/10.1007/s10639-013-9293-5

[20] N. Bakir, C. Devers, and B. Hug, "Affordances and constraints of a blended course in a teacher professional development program,” J. Educ. Mul-timed.Hypermedia, vol. 25, no. 4, pp. 323-341, 2016.

[21] M. Mohamad, H. Hussin, and S. Shaharuddin, "Adult Learners' Perceptions of Designed Hypermedia in a Blended Learning Course at a Public University in Malaysia.," Turk. Online J. Educ. Technol.-TOJET, vol. 14, no. 1, pp. 31-38, 2015.

[22] Y.-W. Lin, C.-L. Tseng, and P.-J. Chiang, "The Effect of Blended Learning in Mathematics Course.” Eurasia J. Math. Sci. Technol. Educ., vol. 13, no. 3, 2017.

[23] Y. Darlington and D. Scott, Qualitative research in practice: stories from the field. Crows Nest, NSW: Allen \&Unwin, 2002.

[24] R. K. Yin, Qualitative research from start to finish. New York: Guilford Press, 2011.

[25] A. Marks, A.-A. Maytha, and K. Rietsema, "Learning Management Systems: A Shift toward Learning and Academic Analytics," Int. J. Emerg. Technol. Learn. IJET, vol. 11, no. 04, pp. 77-82, 2016. https://doi.org/10.3991/ijet.v11i04.5419

[26] N. N. M. Kasim and F. Khalid, "Choosing the right learning management sys-tem (LMS) for the higher education institution context: a systematic review," Int. J. Emerg. Technol. Learn. IJET, vol. 11, no. 06, pp. 55-61, 2016. https://doi.org/10.3991/ijet.v11i06.5644

[27] W. I. O’Byrne and K. E. Pytash, "Hybrid and blended learning," J. Adolesc. Adult Lit., vol. 59, no. 2, pp. 137-140, 2015.

[28] A. Tzikopoulos, N. Manouselis, K. Kastrantas, and C. Costopoulou, "An online information system to support blended training of rural SMEs on e-government," Program, vol. 46, no. 1, pp. 123-143, 2012. https://doi.org/10.1108/00330331211204593 
[29] R. Echeng and A. Usoro, "E-learning implementation issues and strategies to address low participation using an enhanced model of acceptance of web 2.0 technologies: A case study of a scottish university,” Int. J. E-Learn., vol. 16, no. 1, pp. 5-22, 2017.

[30] E. Laine, M. Veermans, A. Lahti, and K. Veermans, "Generation of Student Interest in an Inquiry-Based Mobile Learning Environment.," Frontline Learn. Res., vol. 5, no. 4, pp. 42-60, 2017. https://doi.org/10.14786/flr.v5i4.306

[31] A. Saiger, "Homeschooling, virtual learning, and the eroding public/private binary," J. Sch. Choice, vol. 10, no. 3, pp. 297-319, 2016. https://doi.org/10.1080/15582159.2016.120 2070

[32] Š. Bagon, M. Gačnik, and A. I. Starcic, "Information Communication Technol-ogy Use among Students in Inclusive Classrooms,” Int. J. Emerg. Technol. Learn. IJET, vol. 13, no. 06, pp. 56-72, 2018. https://doi.org/10.3991/ijet.v13i06.8051

[33] J. E. Prescott, K. Bundschuh, E. R. Kazakoff, and P. Macaruso, "Elementary school-wide implementation of a blended learning program for reading inter-vention," J. Educ. Res., vol. 111, no. 4, pp. 497-506, 2018. https://doi.org/10.1080/00220671.2017.1302914

[34] D. Forbes, "Keynote: Going to university-Blended strategies for learning and teaching in a modern tertiary context," J. Open Flex. Distance Learn. vol. 20, no. 2, pp. 21-23, 2016.

[35] R. Schechter, P. Macaruso, E. R. Kazakoff, and E. Brooke, "Exploration of a blended learning approach to reading instruction for low SES students in early elementary grades," Comput. Sch., vol. 32, no. 3-4, pp. 183-200, 2015. https://doi.org/10.1080/07380569.20 15.1100652

[36] P. Kellereret al., "Transforming K-12 Rural Education through Blended Learn-ing: Teacher Perspectives.," Int. Assoc. K-12 Online Learn., 2014.

[37] J. Loizzo and P. Lillard, "In the field: Increasing undergraduate students' awareness of Extension through a blended project-based multimedia production course," J. Ext., vol. 53, no. $1,2015$.

[38] K. Jusoff and R. Khodabandelou, "Preliminary study on the role of social pres-ence in blended learning environment in higher education.," Int. Educ. Stud., vol. 2, no. 4, pp. 7983, 2009.

[39] L. M. Jeffrey, J. Milne, G. Suddaby, and A. Higgins, "Blended learning: How teachers balance the blend of online and classroom components." J. Inf. Tech-nol. Educ., vol. 13, 2014. https://doi.org/10.28945/1968

[40] D. Levy, "Online, Blended and Technology-Enhanced Learning: Tools to Facil-itate Community College Student Success in the Digitally-Driven Workplace.," Contemp. Issues Educ. Res., vol. 10, no. 4, pp. 255-262, 2017. https://doi.org/10.19030/cier.v10i4.100 $\underline{39}$

[41] R. Stroud, B. Drayton, K. Hobbs, and J. Falk, "Interactive whiteboard use in high-tech science classrooms: Patterns of Integration,” Int. J. Emerg. Technol. Learn. IJET, vol. 9, no. 9, pp. 41-49, 2014. https://doi.org/10.3991/ijet.v9i9.4141

[42] J. Mbale, "African Youth Utilising IT-Essentials Innovation in Re-vitalisation of PCs to Equip Disadvantaged Rural Schools Shaping their ICT Learning Landscape: Namibian Case Study," Int. J. Emerg. Technol. Learn. IJET, vol. 9, no. 4, pp. 68-71, 2014. https:// doi.org/10.3991/ijet.v9i4.3560

[43] R. Austin, A. Rickard, and J. Reilly, "Face-to-face contact in blended learning for intercultural education: the role of teachers," Ir. Educ. Stud., vol. 36, no. 3, pp. 323-340, 2017. https://doi.org/10.1080/03323315.2017.1327364

[44] R. Austin, A. Rickard, and J. Reilly, "Face-to-face contact in blended learning for intercultural education: the role of teachers," Ir. Educ. Stud., vol. 36, no. 3, pp. 323-340, 2017. https://doi.org/10.1080/03323315.2017.1327364 
[45] J. M. Pima, M. Odetayo, R. Iqbal, and E. Sedoyeka, "A Thematic Review of Blended Learning in Higher Education," Int. J. Mob. Blended Learn. IJMBL, vol. 10, no. 1, pp. 111, 2018. https://doi.org/10.4018/ijmbl.2018010101

[46] R. Owston, "Empowering Learners Through Blended Learning," Int. J. E-Learn., vol. 17, no. 1 , pp. 65-83, 2018.

[47] R. Dwaik, A. Jweiless, and S. Shrouf, "Using Blended Learning to Enhance Student Learning in American Literature Courses.” Turk. Online J. Educ. Technol.-TOJET, vol. 15, no. 2, pp. 126-137, 2016.

[48] C. Ford, D. McNally, and K. Ford, "Using Design-Based Research in Higher Education Innovation.” Online Learn., vol. 21, no. 3, pp. 50-67, 2017. https://doi.org/10.24059/olj. $\underline{\mathrm{v} 21 \mathrm{i} 3.1232}$

\section{Authors}

Rasmitadila is a researcher and lecturer of Elementary School Teacher Education Department of Education Faculty in Djuanda University Indonesia. She has worked in some research project in the field of elementary teacher education, instructional system, curriculum and materials development. She is the Editor of the journals: Didaktika Tauhidi, Tadbir Muwahhid, as peer reviewers in The International Journal of Interdisciplinary Educational Studies, International Electronic Journal of Elementary Education.

Widyasari is a researcher and lecturer of Elementary School Teacher Education Department of Education Faculty in Djuanda University Indonesia. She has worked in some research project in the field of technology of education and blended learning. She is a Chief of Editor of the journals: DidaktikaTauhidi, TadbirMuwahhid.

Megan Asri Humaira is a researcher and lecturer of Elementary School Teacher Education Department of Education Faculty in Djuanda University Indonesia. She has worked in some research project in the field of languange. and instructional design. She is a Editor of the journals: DidaktikaTauhidi, TadbirMuwahhid.

Anna Riana Suryanti Tambunan is a researcher and lecturer of Education in State University of Medan Indonesia. She has worked in some research project in the field of language.

Reza Rachmadtullah is a lecturer and researcher at the Department of Elementary School Teacher Education, of Education Department Universitas PGRI Adibuana, Surabaya, Indonesia. His research interest is instructional multimedia, instructional strategies and inclusive education.

Achmad Samsudin is a lecturer and researcher at the Department of Physics Education, Faculty of Mathematics and Natural Science Education, Universitas Pendidikan Indonesia, Bandung, Indonesia. Now a day, his tenure in academic position is Lektor/Assist. Prof. His research interest is physics education especially in the misconceptions, conceptual change and understanding.

Article submitted 2018-07-27. Resubmitted 2019-10-08. Final acceptance 2019-10-08. Final version published as submitted by the authors. 